\title{
The Key Role of the Financial Regulation in FinTech Ecosystem: A Model Validation
}

\author{
MOHAMMAD FAHMI ARKANUDDIN ${ }^{1}$, FERDINAND D. SARAGIH ${ }^{2}$, \\ BERNARDUS YULIARTO NUGROHO ${ }^{3}$ \\ ${ }^{1}$ Faculty of Administrative Sciences, UNIVERSITY OF INDONESIA, INDONESIA, \\ E-mail: fahmi.arkanuddin@gmail.com and mohammad.fahmi71@ui.ac.id \\ ${ }^{2}$ Faculty of Administrative Sciences, UNIVERSITY OF INDONESIA, INDONESIA, E-mail: saragih_fds@yahoo.com \\ ${ }^{3}$ Faculty of Administrative Sciences, UNIVERSITY OF INDONESIA, INDONESIA, \\ E-mail: nugrohoyuliarto@gmail.com
}

\begin{abstract}
The objective of this research is for describing the key role of financial (FinTech) regulation to manage the risks, keep-up the balance and stability of FinTech ecosystem from the highest impact of risks' in this industry. FinTech lending has grown rapidly in recent years in many countries and becomes a promising business model in the future, because it is a disruptive innovation to today's financial and banking markets. The rapid development of FinTech lending due to the use of internet-based mobile application platforms, so that it is easily accessible by anyone and anywhere, it encourages an increase in lending to the customers, however credit risk (although absorbed by lenders or investors, still indirectly affects the platform operators), experienced an increase due to non performing loan or NPL. The increase in NPL is an important concern for FinTech lending industry stakeholders, and if it is not addressed it will disrupt the FinTech ecosystem, let alone cause systemic risk, it will be the toughest disturbance in the stability of the FinTech ecosystem, considering that the risk of FinTech lending has a significant influence on the FinTech ecosystem, so that if the level of risk increases, it affects the FinTech ecosystem, this condition requires the key role of financial (FinTech) regulation that can mitigate risk, because financial (FinTech) regulation has a very strong correlation or relationship, so that it can mitigate the risks faced. Another key role of financial (FinTech) regulation is to strengthen the FinTech ecosystem, with new elements needed by the industry and encourage the industry to develop the concept of ecosystem-based risk management in this industry, because it is believed that this concept can mitigate risk as well. Fundamental risks in the FinTech lending industry include: (i) credit risk, (ii) operational risk and (iii) liquidity risk, meanwhile pandemic risk is a new element that is also being investigated, the results of the study show that pandemic risk has a positive correlation with start-up FinTech companies, this means that a pandemic still allows this industry to develop and grow. Financial (FinTech) regulation as a key role is supported by 2 (two) main rules, namely (i) regulatory and (ii) supervisory and 2 (two) complementary provisions to strengthen regulations related to IT process support, namely big data analytics, automation \& robotics and FinTech consumer protection agency. The FinTech ecosystem also needs to be strengthened, with new elements needed to exist, such as credit insurance institutions that stand alone and are separated from traditional financial institution element and FinTech consumer protection agency.
\end{abstract}

Keywords: FinTech; FinTech P2P Lending; Risk (Pandemic Risk-Covid 19 Risk); Financial (FinTech) Regulation; FinTech Ecosytem.

JEL Classification: M15, 017, 032

Received: June 29, 2021

Accepted: September 12, 2021 


\title{
El Papel Clave de la Regulación Financiera en el Ecosistema FinTech: Una Validación del Modelo
}

\author{
MOHAMMAD FAHMI ARKANUDDIN ${ }^{1}$, FERDINAND D. SARAGIH ${ }^{2}$, \\ BERNARDUS YULIARTO NUGROHO ${ }^{3}$ \\ ${ }^{1}$ Faculty of Administrative Sciences, UNIVERSITY OF INDONESIA, INDONESIA, \\ E-mail: fahmi.arkanuddin@gmail.com and mohammad.fahmi71@ui.ac.id \\ ${ }^{2}$ Faculty of Administrative Sciences, UNIVERSITY OF INDONESIA, INDONESIA, E-mail: saragih_fds@yahoo.com \\ ${ }^{3}$ Faculty of Administrative Sciences, UNIVERSITY OF INDONESIA, INDONESIA, \\ E-mail: nugrohoyuliarto@gmail.com
}

\begin{abstract}
RESUMEN
El objetivo de esta investigación es describir el papel clave de la regulación financiera (FinTech) para gestionar los riesgos, mantener el equilibrio y la estabilidad del ecosistema FinTech del mayor impacto de los riesgos' en esta industria. Los préstamos FinTech han crecido rápidamente en los últimos años en muchos países y se convierten en un modelo de negocio prometedor en el futuro, ya que es una innovación disruptiva para los mercados financieros y bancarios actuales. El rápido desarrollo de los préstamos FinTech debido al uso de plataformas de aplicaciones móviles basadas en Internet, de modo que es fácilmente accesible por cualquier persona y en cualquier lugar, fomenta un aumento de los préstamos a los clientes, sin embargo el riesgo de crédito (aunque absorbido por los prestamistas o inversores, todavía afecta indirectamente a los operadores de la plataforma), experimentó un aumento debido a los préstamos no productivos o NPL. El aumento de la morosidad es una preocupación importante para las partes interesadas del sector de los préstamos FinTech, y si no se aborda, perturbará el ecosistema FinTech, por no hablar de causar un riesgo sistémico, será la perturbación más dura en la estabilidad del ecosistema FinTech, teniendo en cuenta que el riesgo de los préstamos FinTech tiene una influencia significativa en el ecosistema FinTech, de modo que si el nivel de riesgo aumenta, afecta al ecosistema FinTech, esta condición requiere el papel clave de la regulación financiera (FinTech) que puede mitigar el riesgo, porque la regulación financiera (FinTech) tiene una correlación o relación muy fuerte, de modo que puede mitigar los riesgos enfrentados. Otro papel clave de la regulación financiera (FinTech) es fortalecer el ecosistema FinTech, con nuevos elementos necesarios para la industria y animar a la industria a desarrollar el concepto de gestión de riesgos basado en el ecosistema en esta industria, porque se cree que este concepto puede mitigar el riesgo también. Los riesgos fundamentales en la industria de préstamos FinTech incluyen: (i) el riesgo de crédito, (ii) el riesgo operacional y (iii) el riesgo de liquidez, mientras tanto el riesgo pandémico es un nuevo elemento que también se está investigando, los resultados del estudio muestran que el riesgo pandémico tiene una correlación positiva con las empresas FinTech de nueva creación, esto significa que una pandemia todavía permite que esta industria se desarrolle y crezca. La regulación financiera (FinTech) como papel clave se apoya en 2 (dos) normas principales, a saber, (i) de regulación y (ii) de supervisión y 2 (dos) disposiciones complementarias para reforzar las regulaciones relacionadas con el apoyo a los procesos de TI, a saber, el análisis de grandes datos, la automatización y la robótica y la agencia de protección del consumidor FinTech. También es necesario reforzar el ecosistema FinTech, con la existencia de nuevos elementos, como las entidades de seguro de crédito independientes y separadas del elemento de la entidad financiera tradicional y la agencia de protección del consumidor FinTech.
\end{abstract}

Palabras clave: FinTech; FinTech P2P Lending; Riesgo (Riesgo Pandémico-Riesgo Covid 19); Regulación Financiera (FinTech); Ecosistema FinTech.

Clasificación JEL: M15, 017, 032

Recibido: 29 de Junio de 2021

Aceptado: 12 de Septiembre de 2021 


\section{Introduction}

The Global FinTech Industry was growing up significantly while pandemic-covid 19 era, one of them is FinTech P2P lending. Global market of FinTech P2P lending is going to be worth 1 trillion Dollars. The global trends of FinTech P2P lending (Arnautov, Vit., 2019), namely: (i) smaller to midsize lenders will enter the game, (ii) banks don't intend to give up, (iii) financial inclusion for underbanked areas, (iv) regulations, and the last, (v) The go-to choose for younger audiences. Bavoso, Vincenzo (2019) stated promise and peril global of FinTech P2P lending is credit risk interconnectedness and systemic risks concerns and the opportunity platforms in this sense have started creating a secondary market for start-ups and SME loans.

The digital industry is divided into 3 (three) business sectors (Kearney, AT., 2017), namely: (i) eCommerce; (ii) FinTech and (iii) On demand services. A very interesting development to study at this time is FinTech, according to Dorfleitner et.al. (2017), FinTech is an industry that is moving and dynamic and fast and has many different business models. Dorfleitner et.al. (2017), divides FinTech into 4 (four) business segments, namely (i) financing; (ii) asset management; (iii) payments; and (iv) other FinTechs. Financing includes 2 (two) main segments, namely (i) Crowdfunding and (ii) Credit and Factoring. The crowdfunding segment is divided into 4 (four) sub-segments namely (i) Donation based crowdfunding; (ii) Reward based crowdfunding; (iii) Crowdinvesting and (iv) Crowdlending. The locus of this research is Crowdlending or FinTech peer to peer lending. Ge, Feng, Gu \& Zhang (2017) and Hsueh, S., \& Kuo, $\mathrm{H}$. (2017), define FinTech P2P lending is the process of connecting between 2 (two) peers who do not meet directly, but through mobile application platforms, without going through intermediary institutions or banking institutions. Industry FinTech lending or peer to peer lending, is an industry full of risks, especially credit risk. According to Saunders \& Cornett, (2007) and Grier, Waymond. A, (2007), credit risk is the promised risk of cash flows from loans and securities obtained by financial institutions that are not paid in full. Credit risk is mostly caused by non performing loan or NPL or bank's failure (Grier, Waymond. A, 2007).

Types of risks faced by financial intermediary institutions (Saunders \& Cornett, 2007), include: (i) interest rate risk; (ii) market risk; (iii) credit risk; (iv) off-balance sheet risk; (v) foreign exchange risk; (vi) country or sovereign risk; (vii) technology risk; (viii) operational risk; (ix) liquidity risk and (x) insolvency risk, meanwhile Grier, Waymond, A., (2007), stated that all banks or intermediary financial institutions will face 5 (five) fundamental risk, i.e. (i) credit risk; (ii) liquidity risk; (iii) interest rate risk/IRR; (iv) leverage or solvency risk and (v) operational risk. According to Imerman, Michael B. \& Fabozzi, Frank J, (2020), FinTech risk specifically states that the main issue of FinTech risk is legal risk. According to Giudici, Paolo (2018), FinTech risk explains that the types of FinTech risks, include: (i) credit risk; (ii) systemic risk in peer-to-peer lending; (iii) market risk; (iv) IT operational risks and cyber risks. The FinTech lending or P2P lending industry is high risk, so it needs to be mitigated with certain instruments, such as measurable financial (FinTech) regulations that are assumed to be able to mitigate existing risks, because they have a very strong correlation or relationship with risk.

The risks of FinTech P2P lending Indonesia will face the risks mentioned above, but the specific risks will face credit risk, operational risk and liquidity risk, if the compare other countries of the risks' fintech P2P lending (Bavoso, Vincenzo., 2019), like England, the majority of risks will face the credit risk, liquidity riks, investor risk, and systemic risk. Operation risks have to cover the human errors risk, internal process, IT and cyber-security.

Financial (FinTech) regulation according to Imerman, Michael B. \& Fabozzi, Frank J. (2020), is one of the factors that form a FinTech ecosystem horizontally based on functional areas. Imerman, Michael B. \& Fabozzi, Frank J, (2020), states that there are 2 (two) main rules in financial (FinTech) regulation, including: (i) How FinTech companies should be regulated, including the largest FinTech companies; (ii) Create regulatory technology (RegTech) and supervisory technology (SupTech) as well as other regulations that may allow inclusion in financial (FinTech) regulations, namely big data analytics and automation \& robotics. The FinTech ecosystem also needs to be strengthened and developed, especially elements of the FinTech ecosystem that are relevant to the level of risk faced, according to 
In Lee \& Yong Jae Shin, (2018), states that there are 5 (five) ecosystem elements FinTech, such as: (i) Start-up FinTechs; (ii) Government; (iii) IT Developers; (iv) FinTech Customers and (v) Traditional Financial Institution, in addition to the ecosystem elements that need to be strengthened, another important thing is the selection of the FinTech ecosystem based on the taxonomy. Imerman, Michael B. \& Fabozzi, Frank J., (2020), where is the risk FinTech this can be categorized as a factor forming a FinTech ecosystem horizontally based on functional areas, in addition to risk, another forming factor is financial (FinTech) regulation, funding and valuation. The FinTech (Arner, Douglas W. et.al., 2016), is an industry that is disruptive to the existing financial and banking industry, so it is interesting to develop and have a prospective business and also interesting to be used as research or study material.

Global COVID-19 Fintech Market Rapid Assessment Study that was released in November 2020 by Cambridge Center of Alternative Finance (CCAF), stated that adoption of the digital financial services in the developing countries shown an increase, including Indonesia. There are 2 (two) main factors that support the significant development of Indonesia's FinTech, namely: (i) The growth of internet users (Turban, Efraim et.al., 2003) and smart phones (Williams, Brian K., \& Sawyer, Stancey, C., 2010). (ii) The low level of penetration of banking and financial institutions services. First, (Indonesia Internet Service Provider Association, 2019) states that the growth users of internet and smartphones there are around 196.71 million internet users, around $73.9 \%$ of Indonesia's total population of 268.2 million people in 2019. Types of internet services are used, among others: (i) Mobile Internet; (ii) Household (House); (iii) Offices; (iv) University; (v) Internet cafe and (vi) Cafe and restaurant. Second, the low level of penetration of banking and financial institutions services is indicated by the number of banking and non-bank banking offices and their distribution that has not reached the suburbs, rural areas, remote areas and other areas, meanwhile internet access can reach these areas because of the existence of mobile operators, so they can access P2P lending FinTech services through access to platforms mobile applications. The significant growth of P2P lending FinTech industry companies which is significant in the last 3 (three) years (Financial Services Authority, Indonesia is named OJK), can be shown from the accumulated loan disbursement in December 2018 amounting to IDR 22.6 Trillion and 31 December 2019 amounted to IDR 81.5 Trillion and the position as of September 2020 was IDR 128.7 Trillion, considering that this industrial business is high risk, so it will have an impact on existing credit risk which can be shown from the non-performing loan ratio which has increased. Loan disbursement growth of the P2P lending FinTech in the last three years was influenced by the increase in the number of P2P lending FinTech companies, as of March 31, 2020, there were around 161 companies or FinTech P2P lending providers spread mostly in Greater Jakarta around 151 companies (93.8\%), and Surabaya there are 4 companies (2.5\%), Bandung 2 companies (1.2\%), Yogyakarta 1 company $(0.62 \%)$, Makassar 1 company (0.62\%), Lampung 1 company (0.62\%) and Bali 1 company (0.62\%). The existence of this industrial company fills the void of non-banking institutions on the outskirts of cities, rural areas, remote areas and other areas that have not been reached by office services either banking and non banking institution, while P2P lending FinTech services can reach all of these areas, because of the existence of cellular operator companies, where this service can only be accessed via the internet (Turban, Efraim et.al.,2003).

Based on data Financial Services Authority, (2020), The number of commercial banks is 110 commercial banks and 1,511 rural banks, with 30,691 commercial bank offices and 5,935 rural bank's offices, while the number of multi finance institutions as like: insurance companies is 150 units, financing institutions as many as 243 units, pension funds as many as 221 units, Institution of Credit's Districts as many as 116 units, supporting services for non-bank institution as many as 228 units, micro finance institution as many as 223 units. Along with the development of the FinTech industry in Indonesia, especially the type of peer-to-peer lending FinTech model, hereinafter referred to as FinTech P2P lending or online lending in the last 3 years, the growth of loans' FinTech P2P lending Indonesia is very significant in the last 3 years, as shown by the data above, will of course be related to the credit risk (Saunders \& Cornett,2007; Grier, Waymond, A, 2007), faced by the industry in addition to other risks. Credit risk (Saunders \& Cornett, 2007; Grier, Waymond, A, 2007), seems to be experiencing a movement marked by the growth of non-performing loans or NPLs FinTech P2P lending. 
Non-performing loans or NPLs also increased, namely December 31, 2018 by $1.45 \%$ and December 31, 2019 by $3.65 \%$ and September 2020 position of $8.27 \%$.

\section{Literature Review}

FinTech ecosystem (Imerman, Michael B. \& Fabozzi, Frank J.,2020), consists of two classifications, namely horizontal and vertical FinTech ecosystems. This study uses horizontal FinTech ecosystem because it is more relevant, which is also divided into 2 (two) based on the criteria, namely (i) Functional areas and (ii) Emergence technologies of financial services, where there are 4 (four) components that make up the horizontal FinTech ecosystem, namely: (i) Risk management; (ii) Financial (FinTech) Regulations; (iii) Funding and (iv) Valuation. This reaserch only used 2 (two) constituent components, namely (i) Risk management and (ii) Financial (FinTech) regulation because it is very relevant to the factual problems of Indonesian P2P lending FinTech. The conceptual problem of this research is the determination of the FinTech ecosystem (Imerman, Michael B. \& Fabozzi, Frank J.,2020), and the use of FinTech ecosystem elements (In Lee \& Yong Jae Shin,2018). The factual problem of this research is that the first is FinTech risk or FinTech risk as shown by the data above and the second is financial (FinTech) regulation. The first factual problem is FinTech risk (Imerman, Michael B. \& Fabozzi, Frank J.,2020), and types of risk (Saunders \& Cornett, 2007). What types of risks are inherent and significant in the Indonesian FinTech industry that affect the FinTech ecosystem (Imerman, Michael B. \& Fabozzi, Frank J., 2020); In Lee \& Yong Jae Shin, 2018). The second factual problem is related to financial (FinTech) regulation (Imerman, Michael B. \& Fabozzi, Frank J.,2020), stating financial (FinTech) regulation that there are 2 (two) ways of FinTech innovation that affect FinTech regulation, namely the first regulatory on FinTech companies and secondly supervisiory over FinTech companies and IT companies and their supporting infrastructure and researchers add two elements according to the results of existing empirical studies, namely big data analytics, automation $\&$ robotics and FinTech consumer protection agency. Financial (FinTech) regulations (Ferrarini, Guido, 2017) that create comprehensive guidelines that contain the direction, form and structure of the P2P lending FinTech (Hsueh, S., \& Kuo, H., 2017; Ge, Feng, Gu \& Zhang, 2017), so that this industrial business is prospective and growing rapidly in the future.

Based on the explanation above, this research serves as a model test and confirms the theory of the taxonomy of FinTech ecosystem (Imerman, Michael B. \& Fabozzi, Frank J., 2020); In Lee \& Yong Jae Shin, 2018) and researchers assume that high risks must be managed and mitigated so that they have a research appetite for this industry, through the establishment of a comprehensive ecosystem-based risk and the issuance of regulations. This study is also to analyze the relationship or correlation between exogenous variables, namely risk and financial (FinTech) regulation, as well as to analyze each influence on the endogenous variables of the FinTech ecosystem and if the analysis results show a significant correlation and influence, then the factual problems related to FinTech industrial risk can be managed and mitigated by financial (FinTech) regulation and FinTech ecosystem variables.

The main literatures are used scientific works in the form of books and the latest international scientific journals. The main literature and references for FinTech (Financial Technology) are from Dorfleitner et.al. (2017), while FinTech P2P lending takes references from Hsueh, S., \& Kuo, H., (2017) and Ge, Feng, Gu \& Zhang, (2017).

The FinTech ecosystem refers to the main journal references from (Imerman, Michael B. \& Fabozzi, Frank J.,2020), (Vovchenko et.al., 2019), (Blyablina, 2019), (Diemers et.al.,2015) and (In Lee \& Yong Jae Shin, 2018). Risk Management uses the main literature from (Imerman, Michael B. \& Fabozzi, Frank J.,2020), (Saunders \& Cornett,2007), (Grier, Waymond, A,2007) and Giudici, Paolo (2018). Financial (FinTech) regulations are sourced from the journals (Imerman, Michael B. \& Fabozzi, Frank J.,2020), (Nambisan, Satish, 2018); (Ferrarini, Guido, 2017) and from Barlow, Mike (2016).

The grand theory used in this research is the FinTech ecosystem (Imerman, Michael B. \& Fabozzi, Frank J.,2020; In Lee \& Yong Jae Shin, 2018) and the substantive theory is risk management (Saunders \& Cornett, 2007; Grier, Waymond, A, 2007; Imerman, Michael B. \& Fabozzi, Frank J., 2020) and Financial (FinTech) regulation from Imerman, Michael B. \& Fabozzi, Frank J., (2020), Nambisan, Satish 
(2018), and Ferrarini, Guido (2017). Risk management and risk use the main literature, among others, namely: (i) Hull, John C. (2018); (ii) Schell, Charles \& Collett, Nick (1992); (iii) Klement, Joachim (2015) (iv) Pompian, Michael M. (2016).

Previous research that is relevant to this research is the journal of Imerman, Michael B. \& Fabozzi, Frank J., (2020), who examines the FinTech taxonomy and divides the FinTech ecosystem into 2 (two) classifications, namely horizontal and vertical FinTech ecosystems, where the horizontal FinTech ecosystem is divided into 2 (two) criteria based on functional areas and the emergence of technology financial services and journals from In Lee \& Yong Jae Shin (2018), which examines the elements of the FinTech ecosystem. This research is to combine these 2 (two) theories, where research is carried out to analyze the correlation of financial (FinTech) regulation variables to risk and analyze the influence of risk on the FinTech ecosystem and analyze the influence of financial (FinTech) regulation on the FinTech ecosystem and to prove or confirm the model from Imerman, Michael B. \& Fabozzi, Frank J., (2020) about the factors forming the FinTech ecosystem horizontally, meanwhile the researcher will develop the concept of FinTech ecosystem elements from In Lee \& Yong Jae Shin (2018).

\section{Methodology}

\subsection{Population and Sampling Research}

The sample is a part or proportion of a group of individuals who have the same characteristics as close to the population (Creswell, John W., 2009). Purposive sampling (Creswell, John W., 2009) is a participant or respondent who assists researchers in understanding or answering problems in research questions. The purpose of purposive sampling (Creswell, John W., 2009) is to solve research problems and can provide a more representative value. The sampling technique uses non-probability sampling (Creswell, John W., 2009) by purposive sampling from end-users of P2P lending and interview from FinTech industry Stakeholders, namely several samples from start-up FinTech companies, the Indonesian FinTech P2P Lending Association; Government (Financial Service Authority, Indonesia is named OJK) and Traditional Financial Institutions. Determining purposive sampling with criterias of end-user FinTech P2P Lending are SME entrepreneurs, worker (employees' job) and profesional. Determination of the number of samples is based on Frankel, Jack R \& Norman E. Wallen (1993) for SEM analysis using a minimum of 100 samples, however for this study the sample is determined by 510 samples per parameter (indicator), in this study there are 3 constructs with a total of 18 parameters (indicators), based on the provisions above, the minimum number of samples to be taken in this study is $5 \times 18=90$ respondents, while the samples taken in this study are 150 samples. Taking 150 samples above the minimum samples because an increase the level of representative of respondent. The distribution of questionnaires to purposive sampling (Creswell, John W., 2009) was carried out around period 2020. The sampling method was purposive sampling (Creswell, John W., 2009). The interval scale used to measure the indicators of each variable using a Likert scale, namely by expressing the agree-disagree scale or agree-disagree scale with an interval scale with a value of 1 to 5 . Distributing research questionnaires to end-users of FinTech P2P lending and conducting interviews with all stakeholders who are experts in the field of FinTech P2P lending, ranging from actors/organizers of start-up FinTech companies, FinTech associations, government (Financial Service Authority, Indonesia is named OJK), traditional financial institution, and insurance industry, around $10 \%$ from the total samples (15 experts' respondent).

\subsection{Variables Operationalization}

This study uses 3 variables, namely (i) Risk Construct (ii) Financial Regulation Contruct; (iii) FinTech Ecosystem Constructs. FinTech Ecosystem is A theoritical framework of a FinTech industrial environment consisting of several supporting elements of the ecosystem, where the supporting elements need to coordinate, work together and collaborate in maintaining business stability and developing so that this industrial business is prospective in the future. (Imerman, Michael B. \& Fabozzi, Frank J., 2020; In Lee \& Yong Jae Shin, 2018). Risk is a risk event is the occurrence of an event that 
causes a potential loss. The risk of loss is a loss that occurs as a direct or indirect consequence and risk event. (Saunders \& Cornett, 2007; Grier, Waymond, A, 2007). Financial (FinTech) Regulation is A FinTech innovation landscape that makes regulatory and supervisory roles for industry players and their supporters and uses Big Data Analytics, Automation \& Robotics in its implementation. (Imerman, Michael B. \& Fabozzi, Frank J., 2020); Giudici, Paolo, 2018). The dimensions/indicators of the research construct and can be seen in Table 3.1. below.

Table 3.1 Dimensions and Indicators Research Constructs

\begin{tabular}{|c|c|c|c|}
\hline Constructs & Dimensions & Code & Sources \\
\hline \multirow{7}{*}{$\begin{array}{c}\text { FinTech } \\
\text { Ecosystem }\end{array}$} & Startup FinTech Companies & $\mathrm{ECO}_{1}$ & \multirow{5}{*}{$\begin{array}{l}\text { In Lee \& Yong Jae } \\
\text { Shin (2018) and } \\
\text { Imerman, Michael } \\
\text { B. \& Fabozzi, } \\
\text { Frank J., (2020) }\end{array}$} \\
\hline & Government & $\mathrm{ECO}_{2}$ & \\
\hline & Technology Developer & $\mathrm{ECO}_{3}$ & \\
\hline & FinTech Customers & $\mathrm{ECO}_{4}$ & \\
\hline & Traditional Financial Institution & $\mathrm{ECO}_{5}$ & \\
\hline & Credit Insurance Institution & $\mathrm{ECO}_{6}$ & \multirow{2}{*}{ Researcher } \\
\hline & FinTech Consumers Protection Agency & $\mathrm{ECO}_{7}$ & \\
\hline \multirow{7}{*}{ Risk } & Credit Risk & $\mathrm{RP}_{1}$ & \multirow{4}{*}{$\begin{array}{c}\text { Saunders \& } \\
\text { Cornett (2007) and } \\
\text { Grier, Waymond, } \\
\text { A, (2007). }\end{array}$} \\
\hline & Operation Risk & $\mathrm{RP}_{2}$ & \\
\hline & Market Risk & $\mathrm{RP}_{3}$ & \\
\hline & Liquidity Risk & $\mathrm{RP}_{4}$ & \\
\hline & Legal Risk & $\mathrm{RP}_{5}$ & $\begin{array}{l}\text { Imerman, Michael } \\
\text { B. \& Fabozzi, } \\
\text { Frank J., (2020) }\end{array}$ \\
\hline & Strategic Risk & $\mathrm{RP}_{6}$ & $\begin{array}{l}\text { Grier, Waymond, } \\
\text { A, (2007). }\end{array}$ \\
\hline & Pandemic Risk & $\mathrm{RP}_{7}$ & Researcher \\
\hline \multirow{4}{*}{$\begin{array}{l}\text { Financial } \\
\text { (FinTech) } \\
\text { Regulation }\end{array}$} & $\begin{array}{l}\text { Regulatory } \\
\text { (Regulation of FinTech companies) }\end{array}$ & $\mathrm{ARS}_{1}$ & \multirow{3}{*}{$\begin{array}{l}\text { Imerman, Michael } \\
\text { B. \& Fabozzi, } \\
\text { Frank J., (2020) }\end{array}$} \\
\hline & $\begin{array}{l}\text { Supervisory (Supervision of FinTech } \\
\text { companies and their supporting IT } \\
\text { companies) }\end{array}$ & $\mathrm{ARS}_{2}$ & \\
\hline & $\begin{array}{l}\text { Big Data Analytics and automation \& } \\
\text { Robotics }\end{array}$ & $\mathrm{ARS}_{3}$ & \\
\hline & FinTech Consumers Protection Agency & $\mathrm{ARS}_{4}$ & Researcher \\
\hline
\end{tabular}

Based on Table 3.1. above, it can be explained that the elements of the FinTech ecosystem according to In Le \& Yong Jae Shin (2018), there are 5 (five) elements, namely: (i) Start-up FinTech; (ii) Government; (iii) IT Developers; (iv) FinTech Customers and (v) Traditional Financial Institutions, researchers developed 2 (two) new elements in the FinTech ecosystem elements, namely elements of credit insurance institutions that stand alone and are separated from traditional financial institution element and FinTech consumers protection agency, based on existing empirical studies and interviews. FinTech risk, (Imerman, Michael B. \& Fabozzi, Frank J.,2020) is only discussed related to legal risk and is further developed with the risk theory of Saunders \& Cornett (2007) and Grier, Waymond, A, (2007), which states that there are fundamental risks in the financial business, including credit risk, operational risk, market risk, liquidity risk and strategic, and the researcher adds 1 (one) type of risk, namely pandemic risk, based on existing empirical studies and interview results. Financial (FinTech) regulations (Imerman, Michael B. \& Fabozzi, Frank J.,2020), stated that there are 2 (two) main rules, namely: (i) Regulatory and (ii) Supervisory; equipped with rules for big data analytics, automation \& robotics, and researchers complete the regulatory elements that need to be included in this regulation, namely the FinTech consumers protection agency, based on existing empirical studies and interviews. There are 3 (three) main variables and 18 (eighteen) indicators in this study which are confirmation of the Imerman, Michael B. \& Fabozzi, Frank J. (2020) model for a horizontal FinTech ecosystem based on functional areas, by utilizing only 2 (two) factors out of 4 (four) factors that exists because it is more relevant than the other 2 (two) factors and develops the concept of FinTech ecosystem elements from 5 (five) elements to 7 (seven) elements as well as to analyze the important role of financial (FinTech) regulation in controlling and mitigating risks and maintaining the stability of the FinTech ecosystem. 
Based on Table 3.1. above, the elements of the FinTech ecosystem in this study can be described as in Figure 3.1. below.

Figure 3.1 FinTech Ecosystem Elements

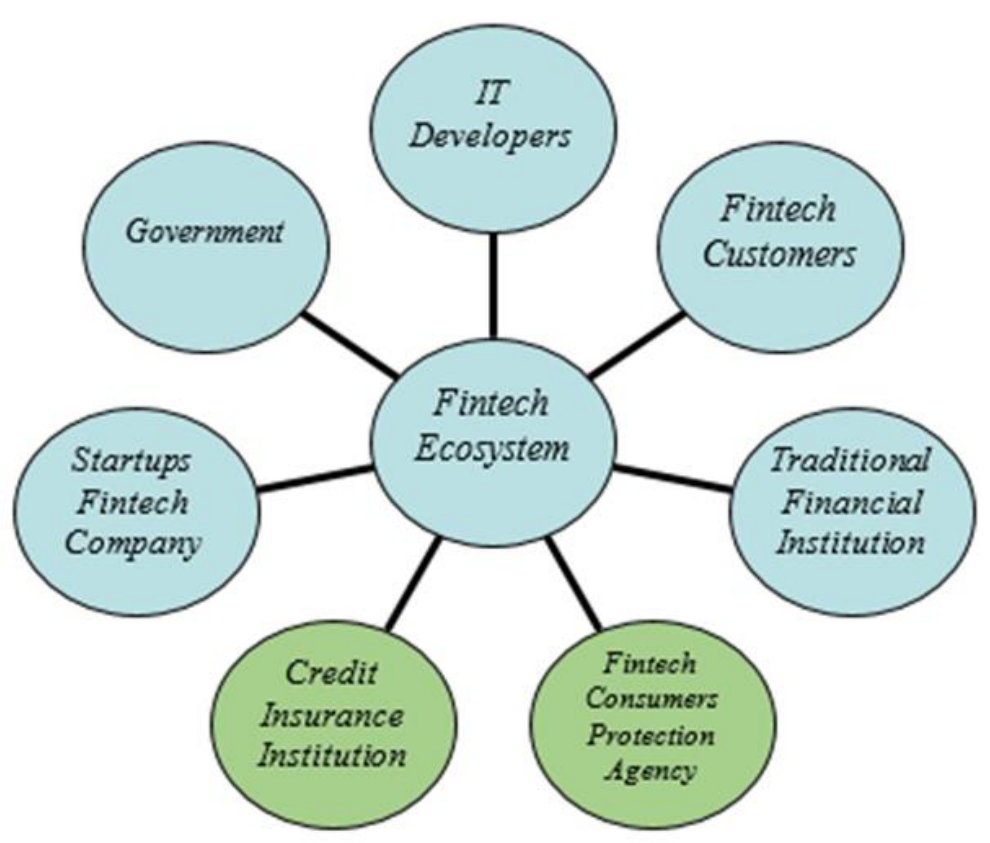

Source: The data has been reprocessed by researchers and is sourced from In Lee \& Yong Jae Shin (2018) and the results of questionare and interviews with industry stakeholders.

FinTech start-up companies as the center of the FinTech ecosystem and is a pioneering company that makes breakthrough innovations in the payment, wealth management, lending, crowdfunding, capital market, and insurances FinTech companies with low operating costs and targets niche markets and provides personalized special services. Governments as financial regulators and legislatures, which have an important role for FinTech startups, some examples of regulations for financial or FinTech (Arner, Douglas W. et.al.,2016), service licensing, tax incentives and relaxation of capital requirements for FinTech startups, loan ceilings, interest rates, and non-performing loans or NPL. IT Developers, help provide and develop digital platforms for use on social media, providing big data analytics, automation $\&$ robotics utilizing cloud computing, cryptocurrency and artificial intelligence development, and utilizing smartphones, and using mobile services. Technology development creates a comfortable environment for FinTech startups to launch qualified innovation services. FinTech customer, as a source of income from FinTech startups, where income can be obtained from individual customers, individual customers of micro, small and medium business entrepreneurs or MSMEs, and other customers from various circles. Traditional financial institutions, consists of traditional banks (Thakor, Anjan V., 2019), stock brokerage firms and venture capitalists. Traditional financial institutions are one element of the FinTech ecosystem, have a very large role and can help collaborate between ecosystem elements, however, traditional financial institutions are currently conducting a through evaluation of their business models and developing new strategies, after the significant impact of FinTech disruptive innovations and trying to embrace and collaborate with FinTech innovation, by providing a variety of funding for FinTech companies, however, it is hoped that FinTech companies in withdrawing their loan funds will still use IT support credit insurance institution is a protection or protection provided by credit insurance institutions to financial institutions (FinTech lending) and banks against the risk of default (failure to pay) in paying off loans or loans provided by these institutions. FinTech consumer protection agency is an institution that has duties and responsibilities in providing protection to consumers by making all efforts to ensure certainty in consumer protection. 


\subsection{Model Validation}

The model validation Imerman, Michael B. \& Fabozzi, Frank J. (2020) is shown in figure 3.2.

Figure 3.2 Model Validation

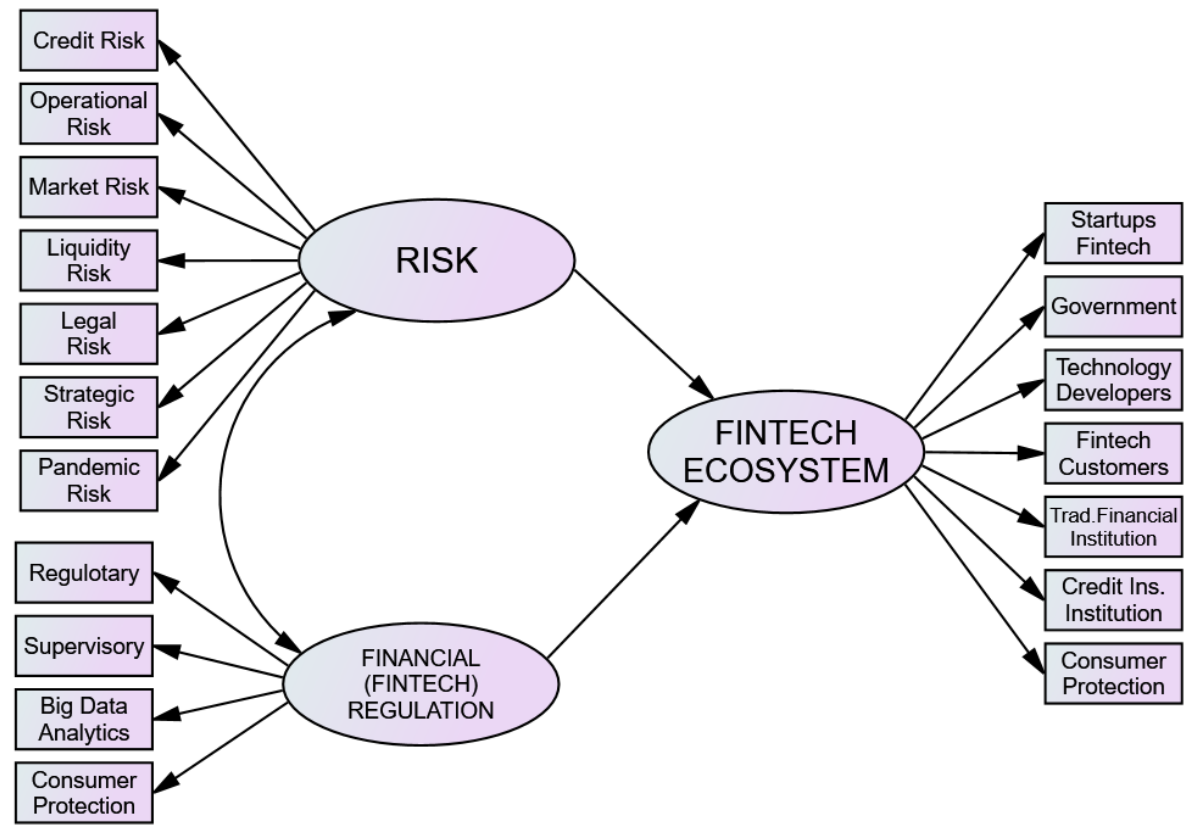

Sources: FinTech Ecosystem (Imerman, Michael B. \& Fabozzi, Frank J.,2020; In Lee \& Yong Jae Shin, 2018)

Based on Figure 3.2. above is the validation of the model, then the hypothesis is what is the important role of financial (FinTech) regulation on risks and the FinTech ecosystem.

\section{Results and Discussion}

\subsection{Respondent Profile}

The total respondents were 150 samples, with profiles, namely: men $56 \%$ and women $44 \%$. $(56.00 \%$ $+44.00 \%=100.00 \%)$. The age of the respondents, $>54$ years, $4.67 \%$ and ages $35-54$ years, $70.00 \%$, and ages $19-34$ years, $25.33 \%$, and age $<19$ years, as much as $0.00 \%(4.67 \%+70.00 \%+25.33 \%+$ $0.00 \%=100.00 \%)$.

Respondents' occupations, employee jobs $71.33 \%$, SME entrepreneurs $22.00 \%$ and others $4.67 \%$ and professional $2.00 \%(71.33 \%+22.00 \%+4.67 \%+2.00 \%=100.00 \%)$. Respondents' positions, directors/management/owners were $23.00 \%$, GM/Division Head positions were $14.00 \%$ and manager positions were $36.00 \%$ and lastly < manager was $27.00 \%(23.00 \%+14.00 \%+36.00 \%+27.00 \%=$ $100.00 \%)$

Educational background of respondents, S-3 (doctoral) is $1.00 \%$, S-2 (post-graduate) is $11.00 \%, \mathrm{~S}-1$ (undergraduate) is $79.00 \%$ and education $<\mathrm{S}-1$ (undergraduatee) is $9.00 \%(1.00 \%+11.00 \%+79.00 \%$ $+9.00 \%=100.00 \%)$

\subsection{Validation Results}

The results of the calculation of the validation test, reliability test, construct reliability test, variance extracted and discriminant validity are shown in Table 4.1. 
Table 4.1 Validation and Reliability Test

\begin{tabular}{|c|c|c|c|c|c|c|}
\hline Variables & $\begin{array}{c}\text { Indicators } \\
\text { Code }\end{array}$ & $\begin{array}{l}\text { Loading } \\
\text { Factor }\end{array}$ & $\begin{array}{l}\text { Construct } \\
\text { Reliability } \\
\end{array}$ & $\begin{array}{l}\text { Variance } \\
\text { Extract }\end{array}$ & $\begin{array}{l}\text { Discriminant } \\
\text { Validity }\end{array}$ & Remarks \\
\hline \multirow{7}{*}{$\begin{array}{l}\text { FinTech } \\
\text { Ecosystem }\end{array}$} & $\mathrm{ECO}_{1}$ & .826 & \multirow{7}{*}{0.9643} & \multirow{7}{*}{0.7947} & \multirow{7}{*}{0.8915} & \multirow{7}{*}{ Fulfill } \\
\hline & $\mathrm{ECO}_{2}$ & .860 & & & & \\
\hline & $\mathrm{ECO}_{3}$ & .849 & & & & \\
\hline & $\mathrm{ECO}_{4}$ & .784 & & & & \\
\hline & $\mathrm{ECO}_{5}$ & .876 & & & & \\
\hline & $\mathrm{ECO}_{6}$ & .801 & & & & \\
\hline & $\mathrm{ECO}_{7}$ & .773 & & & & \\
\hline \multirow{7}{*}{ Risk } & $\mathrm{RP}_{1}$ & .711 & \multirow{7}{*}{0.9516} & \multirow{7}{*}{0.7390} & \multirow{7}{*}{0.8597} & \multirow{7}{*}{ Fulfill } \\
\hline & $\mathrm{RP}_{2}$ & .764 & & & & \\
\hline & $\mathrm{RP}_{3}$ & .652 & & & & \\
\hline & $\mathrm{RP}_{4}$ & .844 & & & & \\
\hline & $\mathrm{RP}_{5}$ & .825 & & & & \\
\hline & $\mathrm{RP}_{6}$ & .865 & & & & \\
\hline & $\mathrm{RP}_{7}$ & .814 & & & & \\
\hline \multirow{4}{*}{$\begin{array}{l}\text { Financial } \\
\text { Regulation }\end{array}$} & $\mathrm{ARS}_{1}$ & .875 & \multirow{4}{*}{0.9549} & \multirow{4}{*}{0.8413} & \multirow{4}{*}{0.9172} & \multirow{4}{*}{ Fulfill } \\
\hline & $\mathrm{ARS}_{2}$ & .884 & & & & \\
\hline & $\mathrm{ARS}_{3}$ & .817 & & & & \\
\hline & $\mathrm{ARS}_{4}$ & .865 & & & & \\
\hline
\end{tabular}

Based on Table 4.1. Data, cut off value loading factor $>0.5$, cut off value construct reliability $>0.70$, cut off value variance extract $>0.5$, based on the data above, all calculation results are met and all indicators are valid and reliable. The stages of SEM testing, which must be passed include: sample number test, data normality test, data outliers test, multicollinearity and singularity test, validity test, reliability test (construct reliability), variance extracted and discriminant validity. The next testing stage is the model estimation test, through the $1^{\text {st }}$ and $2^{\text {nd }}$ Order Instruments (estimation of the measurement model and CFA or Confirmatory Factor Analysis) combined with the CFA test results for the fit latent variable model (fit variables can be used to construct a complete structural equation) and Goodness of Fit or GOF Test), through parameters Df, Chi-Square, Probability, CMIN/Df, RMR, RMSEA, $\mathrm{GFI}, \mathrm{AGFI}, \mathrm{NFI}, \mathrm{RFI}, \mathrm{IFI}, \mathrm{TLI}$ or NNFI, CFI. The next test is the result of the compatibility test: the variable model, whether the model is not fit or fit and finally the hypothesis test

The results of the SEM test according to the stages above, namely: (i) Sample test, as many as 150 samples, fulfilled in accordance with the provisions of the existing sample; (ii) Normality test, the data is normally distributed, so that it is fulfilled; (iii) Outlier data, there are 4 data outliers, so that 4 observation data are excluded and there are no more data outliers, so that they are fulfilled; (iv) There is no multicollinearity and singularity, so that it is fulfilled; (v) Data validity, all indicators have a loading factor above 0.5 , so that all indicators are valid and fulfilled; (vi) Data reliability, all data have construct reliability above 0.7 , so they are reliable and have variance extracted above 0.5 , so they are valid and reliable and all are fulfilled; (vii) Discriminant Validity, the discriminant value is met, for the discriminant validity construct the estimated risk is 0.8597 and the discriminant validity construct of financial regulations is estimated at 0.9172 , how to measure it by comparing to the correlation value between the risk construct and financial (FinTech) regulations is $0.8597>0.841$ and $0.9172>0.841$ ( 0.841 is the coefficient of the relationship between the risk construct and the financial regulation construct); (vii) Testing the $1^{\text {st }}$ order, all of which are met, where the measurement model between constructs and indicators is met, which is above 0.5 ; The $2^{\text {nd }}$ order is also fulfilled and then the CFA test or confirmatory factor analysis between exogenous and endogenous constructs; (viii) Test Results of the complete equation structure model (full model), as for the goodness of fit index or GOFI or Goodness of Fit Index, which includes several parameters, including: (viii.1) Df > 0, Results 29; (viii.2.) Chi-Square < a.df, Result 38.256; (viii.3.) Probability > 0.05, Result 0.117; (viii.4.) CMIN/DF < 2, Result 1.319; (viii.5.) RMR < 0.05, Result 0.020; (viii.6.) RMSEA < 0.08, Result 0.047; (viii.7.) GFI >0.90, Result 0.951; (viii.8.) AGFI > 0.90, Result 0.908; (viii.9.) NFI > 0.90, Result 0.967; (viii.10) RFI > 0.90, Result 0.949; (viii.11) IFI > 0.90, Result 0.992; (viii.12) TLI > 0.90, Result 0.987; (viii.13) NNFI > 0.90, Result 0.987; (viii.14) CFI >0.90, Result 0.992. 
All SEM testing requirements are met, including model testing, resulting in a fit model with a goodness of fit model indicator. The complete model that fits the model produces path coefficient values and CR (critical ratio) and P, to measure the significance of the level of influence. The results of the calculation of the complete model estimate (fit model) for the estimated S.E. (Scalar Estimate) and C.R. (Critical Ratio) and P (Probability) in Regression Weights are shown in Table 4.2.

Table 4.2 Estimate (Maximum Likelihood) and Regression Weight

\begin{tabular}{|c|c|c|c|c|c|c|c|}
\hline \multirow[b]{2}{*}{ Construct } & \multirow{2}{*}{$\begin{array}{l}\text { Indicators } \\
\text { Code }\end{array}$} & \multirow[b]{2}{*}{ C.R. } & \multirow[b]{2}{*}{ P. } & \multirow{2}{*}{$\begin{array}{l}\text { Regression } \\
\text { weight } \\
\text { estimate }\end{array}$} & \multicolumn{2}{|r|}{ C.R. } & P. \\
\hline & & & & & Risk & $\begin{array}{c}\text { Financial } \\
\text { Regulation }\end{array}$ & $\begin{array}{l}\text { Risk and } \\
\text { Fin.Reg. }\end{array}$ \\
\hline \multirow{4}{*}{$\begin{array}{l}\text { FinTech } \\
\text { Ecosystem }\end{array}$} & ECO1 & 12.139 & $\star \star * \star$ & .784 & \multirow{10}{*}{$\begin{array}{l}\text { CR Value } \\
\text { Risk to } \\
\text { FinTech } \\
\text { Ecosystem } \\
\text { estimate } \\
4.675\end{array}$} & \multirow{10}{*}{$\begin{array}{c}\text { CR Value Fin.Reg. } \\
\text { to FinTech } \\
\text { Ecosystem estimate } \\
1.592\end{array}$} & P Value \\
\hline & ECO4 & 12.681 & $\star \star \star *$ & .795 & & & $\begin{array}{l}\text { Risk to } \\
\text { FinTech }\end{array}$ \\
\hline & ECO5 & & $\star \star \star *$ & .897 & & & Ecosystem \\
\hline & ECO7 & 13.257 & $\star * \star *$ & .817 & & & $\underset{* \star *}{\operatorname{Ecosystem}}$ \\
\hline \multirow{4}{*}{ Risk } & RP1 & 10.901 & $* * *$ & .776 & & & And \\
\hline & RP2 & 10.507 & $\star \star * *$ & .749 & & & $\mathrm{P}$ Value \\
\hline & RP4 & & $\star \star * *$ & .843 & & & Fin.Reg.to \\
\hline & RP7 & 10.238 & $* * *$ & .739 & & & FinTech \\
\hline \multirow{2}{*}{$\begin{array}{l}\text { Financial } \\
\text { (FinTech) } \\
\text { Regulation }\end{array}$} & ARS1 & & $\star * *$ & .907 & & & Ecosystem \\
\hline & ARS2 & 15.094 & $\star \star *$ & .891 & & & $\begin{array}{c}\text { Estimate } \\
0.111 \\
\end{array}$ \\
\hline
\end{tabular}

Based on table data 4.2. above, almost all indicators have $C R$ and $P$ values above the $C R$ cut off value, which is $>1.96$ and the $P$ cut off value is 0.05 and the value of $* * *$ (close to zero), meanwhile the $C R$ and $P$ risk construct values are 4.675 and ${ }^{* * *}$, indicating that it has a significant effect on the FinTech ecosystem while the $C R$ and $P$ values of the financial (FinTech) regulation construct are 1.592 and 0.1111 , indicating that the financial regulation construct has no significant effect on the FinTech ecosystem FinTech construct. Correlations results, can be explained positive and negative correlations between indicators, namely: (i) Positive and Significant Correlation of Risk to Financial Regulation estimate of 0.881 ; (ii) Pandemic Risk (e1/RP $)$ has a positive correlation with Startups FinTech Company (e12/ECO1) of estimate 0.373.; (iii) Regulatory (e11/ARS 1 ) has a positive correlation with FinTech consumer protection agency $\left(\mathrm{e} 18 / \mathrm{ECO}_{7}\right)$ of estimate 0.140 , the last (iv) Credit Risk $\left(\mathrm{e} 7 / \mathrm{RP}_{1}\right.$ ) has a negative correlation with Start-up FinTech $\left(\mathrm{e} 12 / \mathrm{ECO}_{1}\right)$ of estimate -0.209 .

\subsection{Structural Equation}

Based on the Amos print output above, there is no significant difference between the covariance matrix of the data from the observed variables and the covariance matrix of the specified model (implied covariance matrix). This shows that the structural equations generated by the full model yang fit model, in this study can be used to explain the relationship or correlation and the significant effect between exogenous variables and their endogenous variables. The structural equations generated by the full model yang fit model are formed from the output of AMOS 23.00 on Standardized Regression Weights: (Group number 1 - Default model), namely:

FinTech Ecosystem $=0.754 *$ Risk $+0.227 *$ Financial $($ FinTech) Regulation + e- 0.077

(Note: The error or residual structural equation is 0.077 obtained from $1-0.923$ which is taken from the Squared Multiple Correlations).

Structural equations can be formed based on the standard estimated values contained in the path diagram. The diagram of the path coefficients obtained from the structural equation can be seen in Figure 4.1. Path Coefficient Diagram, as follows: 
Figure 4.1 Result of Path Coefficient Diagram

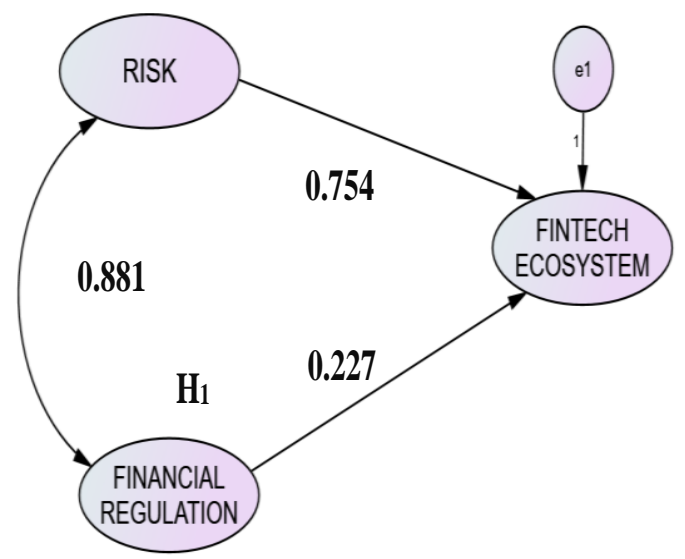

The Analysis of path diagram result of Figure 4.1. in mentioned above, as below:

The risk construct has significant correlation to the financial (FinTech) regulation construct, with a correlation coefficient estimate of 0.881 . Reject $\mathrm{H}_{0}$ and accept $\mathrm{H}_{1}$, so it can be concluded that the risk and financial (FinTech) regulation has a positive and significant and the the stongest correlation. The risk construct has a significant total effect on the FinTech ecosystem construct with a path coefficient estimate of 0.754 . Reject $\mathrm{H}_{0}$ and accept $\mathrm{H}_{1}$, so it can be concluded that the risk and FinTech ecosystem has a significant effect. Financial (FinTech) regulation Construct has a less significant total effect on the FinTech ecosystem construct with a path coefficient estimate of 0.227 . Reject $\mathrm{H}_{0}$ and accept $\mathrm{H}_{1}$, so it can be concluded that the financial (FinTech) regulation and FinTech ecosystem has a less effect. The Risk and Financial (FinTech) Regulation have a significant effect and simultanously to FinTech ecosystem, estimate of 0.923 . Reject $\mathrm{H}_{0}$ and accept $\mathrm{H}_{1}$, so it can be concluded that the risk and Financial (FinTech) regulation has a significant effect the ecosystem.

\subsection{Hypothesis test}

Hypothesis was developed only one as follows: What the exist of correlations and influence risk construct and financial (FinTech) regulation construct as simultaneously on FinTech ecosystem. Hypothesis test was developed based on the theory of Imerman, Michael B. \& Fabozzi, Frank J. (2020) that stated the horizontal Fintech ecosystem is formed by risk management and financial (FinTech) regulation, and confirms and proves the model of correlations and influences the exist inter variables.

Subsequently, the research hypothesis was tested. Testing is carried out on 1 (one) hypothesis proposed. Hypothesis testing is done by using path diagrams (path analysis result), so that what is used is the standardized total effect and the standardized direct effect of exogenous constructs to endogenous constructs

Based on the results of the hypothesis, it can be concluded that the important role of financial (FinTech) regulation and the FinTech ecosystem is the $1^{\text {st }}$ key role, namely being able to mitigate risk, because it has a very strong relationship with risk, it is believed to be able to mitigate risk, if the risk has been mitigated earlier, then will not affect the FinTech ecosystem and the $2^{\text {nd }}$ key role of financial (FinTech) regulation, can strengthen the FinTech ecosystem, by developing new FinTech ecosystem elements needed in this industry, so that the industry can develop in the future and the $3^{\text {rd }}$ key role, is encourage the industry to prepare for the development of an ecosystem based risk management concept, which strengthens and optimizes coordination, cooperation and collaboration between elements of the FinTech ecosystem so that the ecosystem becomes strong and stable and can support the business development of this industry in the future. The Summaries of Result Analysis are as follows:

1. The FinTech industry is an industry that grew very rapidly and significantly in the early days of its emergence, as evidenced by the increasing distribution of loan funds, this significant increase is also 
a driver of increased risk, especially credit risk caused by non-performing loans or NPLs, if the existing risks are not If overcome, it can cause systemic risk (Battiston, S., et.al., 2012), in the FinTech lending industry, and there is a need for regulation, namely financial regulation or FinTech regulation.

2. The key role of financial (FinTech) regulation is very important, because it can mitigate risks so that risks can be avoided and/or controlled and ultimately do not have an impact on the FinTech ecosystem, thereby maintaining the stability of the FinTech ecosystem and being able to develop its business in the future. Financial (FinTech) regulation can also play a role in providing the basis and guidance and direction for the development of the FinTech lending industry in the future and another key role is to encourage coordination, cooperation and collaboration between existing ecosystem elements in order to strengthen the FinTech ecosystem and work together with the banking and finance ecosystem others to support the development of this industry.

3. This key role of financial (FinTech) regulation is supported by 2 (two) main rules, namely regulatory and supervisory, namely the function of the authority in issuing various rules and regulations related to FinTech P2P lending and Supervisory, supervisor must be carried out properly and regularly by the regulator so that this industry can run on track in accordance with existing provisions and regulations

4. Fundamental risk of the FinTech lending industry, namely: (i) credit risk; (ii) operation risk and liquidity risk.

5. Pandemic risk is also analyzed in this study and the results show that pandemic risk has a positive correlation or relationship with start-up FinTech companies, so it can be said that with the COVID19 pandemic, the FinTech lending industry can actually still grow and develop depending on tactics and strategies run by a FinTech lending start-up company.

6. The FinTech ecosystem is an endogenous construct and has central elements, namely: the government as the authority in issuing financial regulations, and has 2 (two) important roles as mentioned above, meanwhile the core elements of the FinTech ecosystem are; (i) Start-up FinTech companies; (ii) FinTech Customers and (iii) Traditional Financial Institutions, meanwhile other elements as supporting elements of the core elements of the FinTech ecosystem such as: (i) IT Developers; (ii) Credit Insurance Institution and (iii) FinTech Consumers Protection Agency. Startups FinTech companies are an important core element of the ecosystem, considering that the main actors are all companies that have P2P lending FinTech businesses. FinTech Customers are an important core element, because whether a business develops or not depends on how many clients/customers there are, the bigger it is, the bigger the business size and business volume. Traditional Financial Institutions are an important core element, because all business transactions of FinTech industry will be processed by banking institution. FinTech Consumer Protection Agency protects cosnsumer (investor and borrowers). The most important things of core elements of FinTech ecosystem are the existances of government, as well as a central regulator and supervisory all the businesses of FinTech industry.

7. The FinTech ecosystem can actually carry out its role in mitigating existing risks apart from financial regulation which plays a key role, namely being able to develop the concept of ecosystem based risk management, in an effort to mitigate the risks faced according to the level of risk and to strengthen the FinTech ecosystem in an effort to strengthen coordination, cooperation and collaboration between ecosystem elements in this industry in carrying out risk mitigation efforts and other matters. The concept of ecosystem-based risk management has been widely used in other industries, such as the maritime industry, etc.

8. The development of the concept of the industrial health level parameter, through the application of a risk based FinTech rating or RBFR (researcher, 2021), which is measured on a risk rating basis, which consists of several elements included in the risk rating, among others, for example: (i) transparency, (ii) ) customer protection, (iii) technology security in addition to important financial indicators such as NPL and equity and other elements according to the needs of this industry.

9. This study validates or confirms the model of the FinTech taxonomy, especially the components that make up the horizontal FinTech ecosystem developed by Imerman, Michael B. \& Fabozzi, Frank 
J.,(2020) as well as the development of the concept of the In Lee \& Yong Jae Shin (2018) FinTech ecosystem which includes 5 (five) elements, while being able to developed into 7 (seven) elements with 2 (two) additional elements of the FinTech ecosystem, namely credit insurance institutions and FinTech consumer protection agency according to the current needs of this industry and in the future there may be a number of existing ecosystem elements, according to the risks faced this industry.

\section{Discussion}

Based on the results of research using a quantitative approach with Path Analysis-Amos analysis tool, this research has implications for the importance of issuing various regulations or policies from the authorities, so that this high-risk business can be mitigated, with risks that are well controlled and mitigated. the effect of risk on the ecosystem is managed properly, so that the ecosystem that is formed is dynamic and flexible, it is necessary to develop the concept of ecosystem-based risk management in this industry, where the ecosystem will adjust to the large or small risks faced and can adjust also to the high or low the impact of these risks. Regulations on the FinTech need to be made and determined immediately so that the business direction of this industry in the future is clear and prospective, where regulatory and supervisory functions from the authorities can be carried out optimally because they can help to manage business risks in this industry.

\subsection{Theoritical implication}

The implication to regulation that is implemented by authority (regulator) for issueing many relevant regulations for mitigating the risks without rigid regulations and limitation in FinTech P2P lending industry and keep up the balancing and stability FinTech ecosystem for the high-risk impact of FinTech P2P lending industry.

\subsection{Limitation}

This research was done in period 2020, so the main focus was the risks, because that period there was the extra event which is pandemic-covid-19, but after the pandemic the main focus may change as well as the changing of external environment.

\subsection{Suggestion For Future Research}

The next research to complete by adding 1 (one) variable such as funding and valuation, so that should cover all variables that formed the horizontal FinTech ecosystem.

\section{Conclusion}

The Indonesian P2P Lending FinTech industry is a prospective industry in the future, because it utilizes internet-based technology on its application platform, so that it can be accessed by anyone and from anywhere who needs financial support. This industry fills the service gap (service vacancies) in areas that have not been reached by the services of traditional financial institutions such as banks, non-bank financial institutions or rural banks. The P2P lending FinTech industry is a high risk industry, so the existing risks need to be managed and mitigated, according to the research results, there are 2 (two) ways to manage and mitigate this high risk, namely by issuing adequate financial (FinTech) regulations, due to the strong relationship or correlation between risk and Financial (FinTech) regulation, so that issuing regulations is very useful in managing and mitigating risk and another way is to apply the concept of a risk-based ecosystem or ecosystem based on risk management, considering that the effect of risk is very significant on the ecosystem, so that ecosystem elements are flexible depending on whether the risk is high or low. The risk of the COVID-19 pandemic is one of the risks analyzed in this study and has a positive influence on startups FinTech companies, meaning that the existence of the COVID-19 pandemic can encourage this industrial business to grow positively and significantly, if FinTech companies startups can take advantage of this momentum. The main regulation 
of FinTech is related to the regulatory function of the authorities, namely issuing regulations that are more adequate to support the development of this industrial business in addition to regulations related to its supervision, because the two regulations are very important and complement each other.

The Indonesian FinTech ecosystem needs to be supported by two other elements, namely the existence of credit insurance institutions and FinTech consumer protection agency, so that credit risk is minimized and consumer complaints or complaints can be handled properly and appropriately. The need to develop comprehensive ecosystem-based risk management concept, in which this concept can help mitigate the high risks of this industrial business, ecosystem elements are flexible and adapt to the high-low risks faced, thus will gain the risk acceptance and risk appetite expected from this industry. Strengthening the use of internet/web-based technology that is easily accessible by anyone and from anywhere by strengthening the application of IT where this is a breakthrough in overcoming the risks of the Pandemic-Covid 19 where the use of IT helps companies to exist and thrive despite events pandemic-covid 19.

\section{References}

1. Arnautov, V. (2019). 7 Key trends in the peer to peer (P2P) lending industry to prepare for. https://www.fintechscotland.com/7-key-trends-in-the-p2p-lending-industry-to-prepare-for/

2. Arner, Douglas W., et.al. (2016). The Evolution of FinTech: A New Post-Crisis Paradigm? SSRN Electronic Journal. DOI: 10.2139/ssrn.2676553.

3. Arner, Douglas W., et.al. (2016). FinTech, RegTech and the Reconceptualization of Financial Regulation. Northwestern Journal of International Law \& Business. 37 (3), 371.

4. Barlow, M. (2016). Evolving Architectures of FinTech. O'Reilly Media, Inc. ISBN: 139781491967768.

5. Battiston, S., et.al. (2012). Liaisons dangereuses: Increasing connectivity, risk sharing, and systemic risk. Journal of Economic Dynamics and Control. 36 (8), 1121-1141. DOI: 10.1016/j.jedc.2012.04.001.

6. Bavoso, V. (2019). The promise and perils of alternative market-based finance: the case of P2P lending in the UK. Journal of Banking Regulation. 21. 395-409.

7. Blyablina, A. (2019). Six key elements to building a successful FinTech Ecosystem.

8. Creswell, J, W. (2009). Research Design: Qualitative, Quantitative, and Mixed-Method Approaches. ( $3^{\text {rd }}$ ed.). Sage Publications.

9. Diemers et.al. (2015). Developing a FinTech Ecosystem in the GCC. Retrieved from https://www.strategyand.pwc.com/media/file/Developing-a-FinTech-ecosystem-in-the-GCC.pdf

10. Dorfleitner et.al. (2017). Definition of FinTech and Description of the FinTech Industry. DOI:10.1007/978-3-319-54666-7_2.

11. Ferrarini, G. (2017). Regulating FinTech: Crowdfunding and Beyond. European Economy.

12. Frankel, Jack R \& Norman E. Wallen. (1993). How to design and Evaluate Research in Education (2 ${ }^{\text {nd }}$ ed.). New York: McGraw hill Inc.

13. Ge, Feng, Gu \& Zhang. (2017). Predicting and Deterring Default With Social Media Information In Peer To Peer Lending. Journal of Management Information System.34 (2).

14. Giudici, P. (2018). FinTech risk management: A reaserch challenge for artificial intelligence in Finance. Frontiers in Artificial Intelligence.1. DOI:10.3389/frai.2018.00001.

15. Grier, Waymond, A. (2007). Credit Analysis of Financial Institution ( $2^{\text {nd }}$ ed.). Euromoney Books.

16. Hsueh, S., \& Kuo, H. (2017). Effective Matching for P2P Lending by Mining Strong Association Rules. Proceedings of the $3^{\text {rd }}$ International Conference on Industrial and Business Engineering. 30-33.

17. Hull, J, C. (2018). Risk Management and Financial Institutions ( $5^{\text {th }}$ ed.). ISBN: 978-1-119-44811-2

18. Imerman, Michael B. \& Fabozzi, Frank J.(2020). Cashing in on innovation: a taxonomy of FinTech. Journal of Asset Management. 21. 167 - 177.

19. In Lee \& Yong Jae Shin. (2018). Fintech: ecosystem, business models, investment decisions, and challenges. Business Horizons. 61(1), 35-46.

20. Kearney, AT (2017). Unleashing Indonesia's digital potential. https://www.Kearney.com/digital/ article/?/a/unleashing-indonesia-s-digital-potential. 
21. Klement, J. (2015). Investor Risk Profiling: An Overview. Research Foundation Briefs. 1 (1), 19. https://doi.org/10.2470/rfbr.v1.n1.1

22. Nambisan, S. (2018). Architecture vs. ecosystem perspectives: eflections on digital innovation. Journal of Information and Organization. 28. 104-106.

23. Pompian, M, M. (2016). Risk Profiling through a Behavioral Finance Lens. The CFA Institute Research Foundation. 2 (1).

24. Saunders \& Cornett. (2007). Financial Institution Management: A Risk Management Approach. (6 ${ }^{\text {th }}$ ed.). New York, NY: McGraw-Hill/Irwin.

25. Schell, Charles \& Collett, Nick. (1992). Corporate Credit Analysis. London, Euromoney Books: Prentice-Hall.

26. Thakor, A,V. (2019). FinTech and banking: What do we know? Journal of Financial Intermediation. 41.100833.

27. Turban, Efraim et.al. (2003). Introduction to Information Technology (2 ${ }^{\text {nd }}$ ed.). John Wiley \& Sons, New York.

28. Vovchenko et.al. (2019). FinTech Ecosystem as an Instrument of Sustainable Development Provision. International Journal of Economics and Business Administration. VII (2). 147 -155.

29. Williams, Brian K. \& Sawyer, Stancey, C. (2010). Using Information Technology (8 ${ }^{\text {th }}$ ed.). McGraw Hill. 